\title{
ANALISIS PENGARUH PAJAK DAERAH TERHADAP PENINGKATAN PENDAPATAN ASLI DAERAH DI KABUPATEN MINAHASA
}

\author{
Frangky Martinus Mea \\ Vicky V. J. Panelewen \\ Arie D. P. Mirah
}

\begin{abstract}
This study aims to analyze the effect of Local Tax on Local Revenue in Minahasa District Year 2011-2015. This research was conducted from January to March 2017 in Minahasa District, North Minahasa District and Tomohon City with the object of Local Taxes research from 2011 to 2015. This study uses secondary data obtained from Minahasa District Revenue Office, Regional Finance Board and Asset Manager of Minahasa District, North Minahasa District and Tomohon City and Statistics Agency of Minahasa District. Data analysis used Contribution and Growth Matrix Analysis and Time Series Analysis. This study found that the contribution of local taxes to the original income of the period of 2011-2015 is still below 50 percetn and the local revenue is at the 5 percent level of Central Government Fund Transfer Income to the regions. This has resulted in poor welfare and prosperity of the population reflected in the per capita income level that is still lacking and the level of regional independence is still low. Analysis of regional tax trends for the year 2016-2020 has increased but still below 5 (five) billion rupiah each year so it still needs to be improved.
\end{abstract}

Keywords: local tax, local revenue, potency, evaluation, monitoring welfare, Minahasa District

\begin{abstract}
ABSTRAK
Penelitian ini bertujuan untuk menganalisis pengaruh Pajak Daerah terhadap Pendapatan Asli Daerah di Kabupaten Minahasa Tahun 2011-2015. Penelitian ini dilaksanakan pada bulan Januari sampai dengan bulan Maret tahun 2017 di Kabupaten Minahasa, Kabupataen Minahasa Utara dan Kota Tomohon dengan objek penelitian Pajak Daerah dari tahun 2011 sampai dengan tahun 2015. Penelitian ini menggunakan data sekunder yang diperoleh dari Dinas Pendapatan Daerah Kabupaten Minahasa, Badan Pengelola Keuangan dan Aset Daerah Kabupaten Minahasa, Kabupaten Minahasa Utara dan Kota Tomohon dan Badan Pusat Statistik Kabupaten Minahasa. Analisis data menggunakan Analisis Matriks Kontribusi dan Pertumbuhan dan Analisis Deret Berkala. Penelitian ini menemukan bahwa kontribusi pajak daerah terhadap pendapatan asli daerah kurun waktu 2011-2015 masih di bawah 50 persen dan Pendapatan Asli Daerah berada di level 5 persen atas Pendapatan Dana Transfer Pemerintah Pusat ke daerah. Hal ini mengakibatkan tingkat kesejahteraan dan kemakmuran penduduk masih kurang yang tergambar dari tingkat pendapatan per kapita yang masih kurang dan tingkat kemandirian daerah masih rendah. Analisis tren pajak daerah untuk tahun 2016-2020 mengalami peningkatan namun masih berada dibawah 5 (lima) miliar rupiah setiap tahunnya sehingga masih perlu ditingkatkan.
\end{abstract}

Kata kunci: pajak daerah, pendapatan asli daerah, Kabupaten Minahasa 


\section{PENDAHULUAN}

\section{Latar Belakang}

Pemerintah Daerah dalam menjalankan roda pemerintahan untuk meningkatkan kesejahteraan masyarakat memerlukan dana/pembiayaan yang nantinya akan digunakan untuk pembangunan yang tertata dalam APBD (Anggaran Pendapatan dan Belanja Daerah). APBD adalah rencana keuangan tahunan pemerintah daerah yang dibahas dan disetujui bersama oleh pemerintah daerah dan pimpinan DPRD, dan ditetapkan dengan peraturan daerah. Sumber-sumber penerimaan/ pendapatan daerah yang potensial harus digali secara maksimal, namun tentunya harus sesuai dengan peraturan perundang-undangan yang berlaku, termasuk diantaranya adalah Pajak Daerah. Pajak Daerah yang merupakan komponen dalam APBD adalah sumber pendapatan asli daerah yang harus dikelola dengan baik dan benar sehingga bermanfaat bagi masyarakat secara keseluruhan. Kebijakan pemungutan pajak berdasarkan peraturan daerah diupayakan agar tidak bertentangan dengan pungutan pusat (pajak maupun bea dan cukai). Kebijakan tentang UU No. 28 Tahun 2009 tentang pajak dan retribsusi daerah dimana Pajak Daerah dan Retribusi Daerah dilaksanakan dengan prinsip demokrasi, pemerataan dan keadilan, peran serta masyarakat dan akuntabilitas dengan memperhatikan potensi daerah. Efektifitas sumber pendapatan daerah dengan sendirinya akan meningkatkan produktivitas PAD tapi harus diimbangi dengan biaya yang minimal. Transfer pemerintah pusat ke Pemerintah Kabupaten Minahasa tahun 2011-2015 lebih dari 95 $\%$, sedangkan PAD hanya berkisar kurang dari $5 \%$. Untuk membiayai kegiatan pemerintahan dan pembangunan, Pemerintah Kabupaten Minahasa masih mengandalkan dana transfer keuangan pemerintah Pusat dan Provinsi. Berikut tabel Pajak dan Pendapatan Asli Daerah Kabupaten Minahasa dapat dilihat pada Tabel 1.

Tabel 1. Pajak Daerah terhadap PAD Kabupaten Minahasa Tahun 2011-2015

\begin{tabular}{|c|c|c|c|}
\hline Tahun & Pajak Daerah & PAD & $\begin{array}{l}\text { \% Pajak Daeah } \\
\text { Terhadap PAD }\end{array}$ \\
\hline 2011 & 10.075 .994 .263 & 23.809 .503306 & 42,32 \\
\hline 2012 & 10.419 .017 .784 & 22.477 .366 .444 & 46,35 \\
\hline 2013 & 12.660 .073 .024 & 31.964 .854 .060 & 39,61 \\
\hline 2014 & 19.468 .059 .670 & 58.778 .368 .155 & 33,12 \\
\hline 2015 & 24.792 .193 .897 & 73.125 .539 .559 & 33,90 \\
\hline
\end{tabular}

Tabel 1 menunjukan bahwa pajak daerah memberikan sumbangan yang paling besar pada Pendapatan Asli Daerah Kabupaten Minahasa. Pengelolaan Pajak harus dilakukan secara cermat, tepat dan hati-hati. Pemerintah Daerah perlu memiliki pengendalian yang memadai untuk menjamin ditaatinya sistem dan prosedur kebijakan manajemen yang telah ditetapkan. Selain itu perlu dilakukan penyederhanaan prosedur administrasi yang bertujuan untuk memberi kemudahan bagi masyarakat yang membayar pajak sehingga diharapkan dapat meningkatkan kepatuhan membayar pajak dengan harapan dimasa yang akan datang bisa meningkatkan penerimaan daerah. Pengoptimalkan pendapatan atau penerimaan pajak daerah di Kabupaten Minahasa, terlebih dahulu harus mengetahui/mengkaji seberapa besar penerimaan pajak daerah berdasarkan potensi riil yang mutlak dilakukan untuk menetapkan target rasionalnya. Dengan potensi yang ada dan terukur setelah dibandingkan dengan perkiraan penerimaan masa depan maka akan dapat diperkirakan rencana dan tindakan apa yang harus dilakukan pemerintah daerah untuk mengoptimalkan penerimaan pajak daerah.

\section{Tujuan Penelitian}

Penelitian ini bertujuan untuk menganalisis pengaruh Pajak Daerah terhadap Pendapatan Asli Daerah di Kabupaten Minahasa Tahun 2011-2015.

\section{Manfaat Penelitian}

Hasil penelitian ini diharapkan memberikan informasi dan sumbangan pemikiran dalam menganalisis pengembangan ilmu pengetahuan dalam ilmu sosial ekonomi secara khusus pajak daerah serta dapat memberikan masukan kepada masyarakat dan pemerintah daerah tentang potensi pajak daerah serta meningkatkan kesadaran masyarakat dalam membayar pajak sehingga terjadi peningkatan PAD dan secara khusus penelitian ini diharapkan mampu memberikan masukan bagi pemerintah daerah khususnya Dinas Pendapatan yang tahun 2017 berganti nama Perangkat Daerah menjadi Badan Pengelola Pajak dan Retribusi Daerah dalam merumuskan kebijakan yang menyangkut pajak daerah sehingga terjadi peningkatan kesejahteraan masyarakat. 


\section{METODE PENELITIAN}

1. Penelitian ini dilaksanakan sejak bulan Januari tahun 2017 sampai dengan bulan Maret tahun 2017 di Pemerintah Kabupaten Minahasa, Kabupataen Minahasa Utara dan Kota Tomohon dengan objek penelitian Pajak Daerah dari tahun 2011 sampai dengan tahun 2015.

2. Pengumpulan data sekunder adalah data yang diperoleh dari penelitian secara tidak langsung melalui media perantara yang diperoleh dari Dinas Pendapatan Daerah Kabupaten Minahasa, Badan Pengelola Keuangan dan Aset Daerah Kabupaten Minahasa, Kabupaten Minahasa Utara dan Kota Tomohon dan Badan Pusat Statistik Kabupaten Minahasa.

3. Analisis Matriks Kontribusi dan Pertumbuhan. Analisis Matriks Kontribusi dan pertumbuhan adalah alat analisis yang digunakan untuk menghitung besarnya sumbangan dari sektor tertentu terhadap sektor lainnya yang bertujuan untuk mengetahui seberapa besarnya sumbangan yang dapat diberikan dari sektor tersebut dan sebagai alat untuk menentukan dalam kategori apa sektor tersebut berada dalam peranannya dalam memberikan sumbangan terhadap sektor yang lain apakah prima, potensial, berkembang, atau terbelakang. Perhitungan matriks kontribusi pada variabel penerimaan pajak daerah terhadap PAD dapat dilakukan melalui perbandingan antara Penerimaan pajak daerah dengan Pertumbuhan PAD, sehingga dari analisis tersebut dapat disimpulkan apakah peranan penerimaan pajak daerah Terhadap PAD bersifat Prima, Potensial, berkembang atau Terbelakang. Analis data dengan menggunakan: ratio pertumbuhan, ratio tambahan, proporsi, sedangkan untuk menentukan klasifikasi jenis pajak atau retribusi digunakan hubungan ratio-ratio.

Tabel 2. Rumus untuk Klasifikasi Jenis Pajak atau Retribusi Daerah

\begin{tabular}{|c|c|c|}
\hline $\begin{array}{l}\text { Ratio Proporsi } \\
\text { Ratio Tambahan }\end{array}$ & $\mathrm{X} /$ rerata $>1$ & $\mathrm{X} /$ rerata $<1$ \\
\hline $\mathrm{X} 1 / \mathrm{X} 2>1$ & Prima & Berkembang \\
\hline $\mathrm{X} 1 / \mathrm{X} 2<1$ & Potensial & Terbelakang \\
\hline
\end{tabular}

Tabel 2 menunjuan bahwa analisis elastisitas untuk mencari elastisitas masingmasing pajak daerah terhadap Pendapatan Asli Daerah (PAD) dan PDRB dengan menggunakan rumus :

$$
\begin{aligned}
P A D & =\frac{\triangle_{r}^{P D}}{\triangle^{P A D P D}} \stackrel{P A D}{-} \\
P A D & =\frac{\triangle^{P D}}{\triangle^{P D R B}} \times \frac{P D R B}{P D}
\end{aligned}
$$

4. Analisis Deret Berkala (Time Trend). Penerimaan pajak daerah untuk tahun anggaran mendatang dapat diestimasi dengan menggunakan fungsi aritmatik dari waktu (penerimaan pajak $=a+b T$ ). Analisis deret berkala dilakukan dengan berbagai metode estimasi, yang salah satunya menggunakan Metode Kuadrat Terkecil (The Least Square Method). Metode ini menderet data secara tahunan kemudian memproyeksi kecenderungannya dimasa yang akan datang. Metode Kuadrat Terkecil juga bertujuan untuk meminimumkan jumlah kuadrat penyimpangan (deviasi) nilai terhadap garis tren. Untuk mengetahui pertumbuhan atau perkembangan penerimaan pajak daerah 2011-2015, dapat digunakan formula sebagai berikut (Mardiasmo dan Makhfatih, 2000: 7)

$$
\mathrm{Y}=\mathrm{a}+\mathrm{bT}
$$

5. Variabel Keadilan (Equity), efisiensi (economic efficiency), kemampuan melaksanakan (Ability to implement) dan variabel kesesuaian sebagai penerimaan daerah (Suitability as a Local Source).

\section{HASIL DAN PEMBAHASAN}

Undang-Undang Nomor 28 tahun 2009 pada Bab II Bagian Kesatu Pasal 2 menyebutkan jenis pajak yang dapat dikelola oleh kabupaten/kota meliputi 11 (sebelas komponen) yaitu pajak hotel, pajak restoran, pajak hiburan, pajak reklame, pajak penerangan jalan, pajak mineral bukan logam dan batuan, pajak parkir, pajak air tanah, pajak sarang burung walet, pajak bumi dan bangunan perdesaan dan perkotaan, dan bea perolehan hak atas tanah dan bangunan. Pajak daerah Kabupaten Minahasa beserta realisasinya tahun 2011-20 seperti dalam 
Tabel 3. Tabel 3 menunjukan bahwa pajak daerah mengalami kenaikan dan memberikan kontribusi yang bervariasi terhadap pendapatan asli daerah. Kenaikan pajak daerah tersebut secara kumulatif cenderung mengalami peningkatan dari setiap tahunnya. Pada awal tahun penelitian yaitu pada tahun 2011 pajak daerah di Kabupaten Minahasa pendapatan asli daerah sebesar mampu menyumbang Rp10.075.994.263,00 dan berkembang menjadi Rp10.419.017.784,00 pada tahun 2012. Pada tahun 2013 naik menjadi Rp12.660.073.024,00, tahun 2014 Rp19.468.059.670,00 dan pada tahun 2015 Rp24.792.193.897,00 atau melebihi $100 \%$ selama lima tahun. Berdasarkan tabel 4.1 dapat disimpulkan bahwa sektor yang menyumbang pajak paling tinggi adalah pajak penerangan jalan, pajak mineral bukan logam dan batuan serta Pajak BPHTB yang melebihi penerimaan lainnya di Kabupaten Minahasa. Berdasarkan target pajak daerah tahun 20112015 seperti dalam Tabel 4. Selanjutnya Perkembangan Target Pajak dapat dilihat pada Tabel 5. Tabel 5 menunjukan bahwa peningkatan pajak daerah di Kabupaten Minahasa sangat fluktuatif, variatif dan tergantung kondisi dan tingkat pertumbuhan ekonomi. Dalam kurun waktu lima tahun terakhir pajak penerangan jalan dan pajak mineral bukan logam dan batuan memberikan kontribusi yang sangat besar dan mengalami perkembangan kenaikan dari tahun ke tahun.

Tabel 3. Realisasi Pajak Daerah Kabupaten Minahasa Tahun 2011-2015

\begin{tabular}{|l|l|l|l|l|l|l|}
\hline No & Jenis Pajak Daerah & Tahun 2011 & Tahun 2012 & Tahun 2013 & Tahun 2014 & Tahun 2015 \\
\hline 1 & Pajak Hotel & 2.538 .442 .404 & 1.664 .617 .115 & 2.730 .462 .904 & 2.562 .338 .293 & 2.803 .526 .659 \\
\hline 2 & Pajak Restoran & 1.075 .395 .479 & 1.087 .251 .480 & 1.197 .773 .069 & 1.925 .240 .171 & 1.610 .423 .631 \\
\hline 3 & Pajak Hiburan & 7.718 .000 & 4.208 .000 & 3.225 .000 & 6.100 .000 & 8.600 .000 \\
\hline 4 & Pajak Reklame & 227.787 .433 & 217.404 .667 & 285.909 .823 & 476.307 .859 & 676.249 .144 \\
\hline 5 & PPJ & 3.974 .462 .836 & 3.519 .610 .915 & 3.887 .999 .024 & 4.739 .516 .629 & 6.986 .010 .516 \\
\hline 6 & Pajak MBLB & 1.140 .562 .000 & 2.192 .631 .800 & 2.596 .743 .000 & 3.644 .246 .400 & 4.401 .762 .300 \\
\hline 7 & Pajak Air Tanah & 21.727 .343 & 42.982 .850 & 28.867 .500 & 22.089 .250 & 52.6988 .000 \\
\hline 8 & Pajak Sarang Burung Walet & 22.277 .800 & 18.000 .000 & 21.500 .000 & 3.250 .000 & 25.500 .000 \\
\hline 9 & BPHTB & 1.067 .620 .968 & 1.672 .310 .957 & 1.907 .592 .704 & 2.328 .199 .604 & 3.890 .855 .376 \\
\hline 10 & PBBP2 & & & & 3.760 .771 .464 & 4.336 .568 .271 \\
\hline & Total & 10.075 .994 .263 & 10.419 .017 .784 & 12.660 .073 .024 & 19.468 .059 .670 & 24.792 .139 .897 \\
\hline & Rata-Rata & 1.119 .554 .918 & 1.157 .668 .643 & 1.406 .674 .780 & 1.946 .805 .967 & 2.479 .219 .390 \\
\hline
\end{tabular}

Tabel 4. Target Pajak Daerah Kabupaten Minahasa Tahun 2011-2015

\begin{tabular}{|l|l|l|l|l|l|l|}
\hline No & Jenis Pajak Daerah & Tahun 2011 & Tahun 2012 & Tahun 2013 & Tahun 2014 & Tahun 2015 \\
\hline 1 & Pajak Hotel & 2.525 .000 .000 & 2.570 .000 .000 & 2.613 .800 .000 & 2.643 .800 .000 & 3.053 .100 .000 \\
\hline 2 & Pajak Restoran & 1.652 .500 .000 & 1.472 .500 .000 & 1.325 .700 .000 & 1.830 .700 .000 & 1.682 .750 .000 \\
\hline 3 & Pajak Hiburan & 6.300 .000 & 6.300 .000 & 7.718 .000 & 7.718 .000 & 8.000 .000 \\
\hline 4 & Pajak Reklame & 245.000 .000 & 375.000 .000 & 241.000 .000 & 316.200 .000 & 576.000 .000 \\
\hline 5 & PPJ & 3.881 .375 .000 & $4.500 . .000 .000$ & 3.950 .000 .000 & 4.818 .000 .000 & 6.000 .000 .000 \\
\hline 6 & Pajak MBLB & 1.750 .000 .000 & 2.000 .000 .000 & 2.000 .000 .000 & 2.300 .000 .000 & 4.000 .000 .000 \\
\hline 7 & Pajak Air Tanah & 100.000 .000 & 100.000 .000 & 50.000 .000 & 50.000 .000 & 50.000 .000 \\
\hline 8 & Pajak Sarang Burung Walet & 100.000 .000 & 100.000 .000 & 50.000 .000 & 25.000 .000 & 25.000 .000 \\
\hline 9 & BPHTB & 500.000 .000 & 1.100 .000 .000 & 1.400 .000 .000 & 1.700 .000 .000 & 3.125 .000 .000 \\
\hline 10 & PBBP2 & & & & 5.181 .178 .871 & 5.600 .000 .000 \\
\hline & Total & 10.760 .175 .000 & 12.223 .800 .000 & 11.638 .218 .000 & 18.872 .596 .871 & 24.119 .850 .000 \\
\hline
\end{tabular}

Tabel 5. Perkembangan Target Kenaikan Pajak Daerah Kabupaten Minahasa

\begin{tabular}{|l|l|l|l|l|l|l|}
\hline No & Jenis Pajak Daerah & Tahun 2011 & Tahun 2012 & Tahun 2013 & Tahun 2014 & Tahun 2015 \\
\hline 1 & Pajak Hotel & 2.525 .000 .000 & 2.570 .000 .000 & 2.613 .800 .000 & 2.643 .800 .000 & 3.053 .100 .000 \\
\hline 2 & Pajak Restoran & 1.652 .500 .000 & 1.472 .500 .000 & 1.325 .700 .000 & 1.830 .700 .000 & 1.682 .750 .000 \\
\hline 3 & Pajak Hiburan & 6.300 .000 & 6.300 .000 & 7.718 .000 & 7.718 .000 & 8.000 .000 \\
\hline 4 & Pajak Reklame & 245.000 .000 & 375.000 .000 & 241.000 .000 & 316.200 .000 & 576.000 .000 \\
\hline 5 & PPJ & 3.881 .375 .000 & $4.500 . .000 .000$ & 3.950 .000 .000 & 4.818 .000 .000 & 6.000 .000 .000 \\
\hline 6 & Pajak MBLB & 1.750 .000 .000 & 2.000 .000 .000 & 2.000 .000 .000 & 2.300 .000 .000 & 4.000 .000 .000 \\
\hline 7 & Pajak Air Tanah & 100.000 .000 & 100.000 .000 & 50.000 .000 & 50.000 .000 & 50.000 .000 \\
\hline 8 & Pajak Sarang Burung Walet & 100.000 .000 & 100.000 .000 & 50.000 .000 & 25.000 .000 & 25.000 .000 \\
\hline 9 & BPHTB & 500.000 .000 & 1.100 .000 .000 & 1.400 .000 .000 & 1.700 .000 .000 & 3.125 .000 .000 \\
\hline 10 & PBBP2 & & & 5.181 .178 .871 & 5.600 .000 .000 \\
\hline & Total & 10.760 .175 .000 & 12.223 .800 .000 & 11.638 .218 .000 & 18.872 .596 .871 & 24.119 .850 .000 \\
\hline
\end{tabular}




\section{Analisis Perhitungan Pertambahan, Ratio Pertumbuhan dan Proporsi Penerimaan Pajak Daerah Tahun 2011-2015}

Kinerja Pendapatan/penerimaan daerah, berdasarkan model Penyusunan Program dan Strategi Anggaran dapat ditentukan oleh beberapa indikator/kriteria: (a) Pertumbuhan, Pertumbuhan penerimaan daerah merupakan indikator untuk melihat sejauh mana perkembangan suatu ayat penerimaan dari tahun ketahun. Pertumbuhan dapat meningkat atau menurun dan biasanya dinyatakan dalam prosentase. (b) Kontribusi/Proporsi dari ayat penerimaan daerah merupakan peranan atau sumbangan yang diukur dalam bentuk prosentase suatu ayat penerimaan terhadap total ayat penerimaan (pajak) dan terhadap total penerimaan asli daerah (PAD). Semakin besar angka kontribusinya ini berarti semakin bermakna sumbangan ayat penerimaan daerah tersebut dalam membentuk total penerimaan (pajak) dan total PAD. Selanjutnya untuk menilai kinerja ayat penerimaan daerah, yang selanjutnya digunakan untuk menentukan potensi (mengklasifikasi) ayat penerimaan menjadi 4 klasifikasi yaitu: (1) Penerimaan Prima, Jika ratio tambahan (pertumbuhan) jenis pajak daerah keduanya lebih besar atau sama dengan satu, (2) Penerimaan Potensial, jika ratio tambahan pertumbuhan jenis pajak daerah lebih kecil atau sama dengan satu dan ratio proporsi atau sumbangannya terhadap rata-rata total penerimaan pajak daerah lebih besar atau sama dengan satu. (3) Berkembang, jika ratio pertambahan pertumbuhan jenis pajak daerah lebih besar atau sama dengan satu dan ratio proporsi atau sumbangannya terhadap rata-rata total penerimaan pajak daerah lebih besar atau sama dengan satu. (4) Terbelakang jika ratio Pertambahan pertumbuhan jenis pajak daerah dan ratio proporsinya atau sumbangannya terhadap rata-rata total penerimaan pajak daerah keduanya lebih kecil atau sama dengan satu (Masykur Wiratmo, makalah, 2001). Jika diperhatikan untuk menentukan klasifikasi jenis pajak diperlukan dua indikator pokok, yaitu: (1) Ratio Proporsi, ini merupakan perbandingan antara realisasi suatu ayat pajak dengan rerata pajak daerah. Rerata pajak dapat dihitung dari jumlah seluruh pajak dibagi dengan jumlah ayat pajak/retribusi. (2) Ratio tambahan Pertumbuhan, ratio ini membandingkan pertumbuhan ayat pajak dengan pertumbuhan total pajak. Alternatif kebijakan atau upaya yang dapat diambil atau diterapkan dalam usaha meningkatkan setiap jenis klasifikasi yang disebut diatas akan berbeda-beda. Jika jenis pajak atau retribusi termasuk prima, maka kebijaksanaan yang telah diterapkan pada tahun-tahun sebelumnya dapat tetap digunakan dengan mempertahankan tingkat pertumbuhan dan kontribusinya. Jika Potensial, maka upaya yang perlu dilakukan adalah mengintensifkan pemungutan dari sumber penerimaan yang ada sehingga terjadi pertumbuhan penerimaan. Untuk pajak dengan klasifikasi Berkembang, upaya peningkatan yang dilakukan adalah dengan menggali sumbersumber baru dengan tingkat pertumbuhan seperti pada tahun-tahun sebelumnya. Jika pajak atau retribusi dalam klasifikasi terbelakang, maka upaya peningkatannya dilakukan dengan menggali sumber-sumber penerimaan baru dan meningkatkan penerimaan dari tahun sebelumnya dari sumber peneriman yang ada. Pada penelitian ini menggunakan data perolehan dari pajak daerah tahun 2011-2015. Analisis masing-masing ayat pajak daerah terhadap pajak daerah selama tahun 2011-2015 khusus kontribusi pajak seperti dalam Tabel 6.

Selanjutnya untuk perhitungan ratio pertumbuhan, pertambahan proporsi dapat dilhat pada Tabel 7. Tabel 7 menunjukan bahwa kontribusi dan ratio khususnya menghubungkan antara ratio tambahan dengan ratio proporsi pajak daerah, maka dapat ditentukan klasifikasi potensi pajak daerah pada tahun 2011 sampai tahun 2012 dapat disimpulkan sebagai berikut: (1) pajak hotel dengan ratio tambahan 0,13 dan ratio Proporsi 1,89 maka pajak hotel termasuk pajak potensial dengan kontribusi $21,02 \%$ terhadap total pajak daerah dan $9,52 \%$ terhadap PAD, (2) pajak restoran dengan ratio tambahan $-0,80$ dan ratio proporsi 1,08 maka pajak restoran termasuk pajak potensial dengan kontribusi $12,05 \%$ terhadap total pajak daerah dan $5,45 \%$ terhadap PAD, (3) pajak hiburan dengan ratio tambahan 0,00 dan ratio proporsi 0,00 maka pajak hiburan juga termasuk pajak terbelakang dengan kontribusi $0,05 \%$ terhadap total pajak daerah dan 0,02 \% terhadap PAD, (4) pajak reklame dengan ratio tambahan 3,90 dan ratio proporsi 0,28 maka pajak reklame termasuk pajak berkembang dengan kontribusi 3,07\% terhadap total pajak daerah dan $1,39 \%$ terhadap PAD, (5) Untuk pajak penerangan jalan dengan ratio tambahan 1,17 dan proporsi 3,31 maka pajak penerangan jalan termasuk pajak prima dengan kontribusi $36,81 \%$ terhadap total pajak daerah dan 16,662 \% terhadap PAD, (6) pajak galian $\mathrm{C}$ dengan ratio tambahan 1,05 serta proporsinya hanya 1,47 maka pajak galian $\mathrm{C}$ termasuk pajak prima dengan kontribusi $16,36 \%$ terhadap total pajak daerah dan 7,41\% terhadap PAD, (7) pajak air tanah dengan ratio tambahan 0,00 dan ratio proporsi 0,07 termasuk pajak terbelakang dengan kontribusi $0,82 \%$ terhadap total pajak daerah dan $0,37 \%$ terhadap PAD, (8) pajak sarang burung walet dengan ratio tambahan 0,00 dan ratio proporsi 0,07 
termasuk pajak terbelakang dengan kontribusi $0,82 \%$ terhadap total pajak daerah dan $0,37 \%$ terhadap PAD, dan (9) pajak bea perolehan hak atas tanah dan bangunan (BPHTB) dengan ratio tambahan 8,82 dan ratio proporsinya 0,81 maka pajak BPHTB termasuk pajak berkembang dengan kontribusi $9,00 \%$ terhadap total pajak daerah dan 4,07\% terhadap PAD.

Pertumbuhan penerimaan pajak yang dicapai dari tahun 2011 ke 2012 mencapai 13.60\% dengan rata-rata pendapatan tahun 2012 dari masing-masing ayat pajak sebesar Rp1.358.200.000,00. Dari ke-9 jenis pajak yang dipungut di Kabupaten Minahasa yang klasifikasi pajak potensial yaitu pajak hotel dan restoran dan yang masuk dalam katagori prima yaitu pajak penerangan jalan dan pajak mineral bukan logam dan batuan (MBLB). Dua jenis pajak masuk dalam katagori berkembang yaitu pajak reklame dan pajak BPHTB serta tiga masuk dalam klasifikasi terbelakang yaitu pajak hiburan, air tanah dan sarang burung walet. Meskipun pajak PPJ dan MBLB dikategorikan prima tapi tidak diikuti kontribusi yang signifikan terhadap pajak daerah dan pendapatan asli daerah (PAD) dapat dlihat pada Tabel 8. Berdasarkan Tabel 8 maka, khususnya menghubungkan antara ratio tambahan dengan ratio proporsi pajak daerah, maka dapat ditentukan klasifikasi potensi pajak daerah pada tahun 2012 sampai tahun 2013 dapat disimpulkan sebagai berikut: (1) pajak hotel dengan ratio tambahan 0,36 dan ratio Proporsi 2,02 maka pajak hotel termasuk pajak potensial dengan kontribusi $22,46 \%$ terhadap total pajak daerah dan $8,36 \%$ terhadap PAD, (2) pajak restoran dengan ratio tambahan 2,08 dan ratio proporsi 1,03 maka pajak restoran termasuk pajak prima dengan kontribusi $11,39 \%$ terhadap total pajak daerah dan $4,24 \%$ terhadap PAD, (3) pajak hiburan dengan ratio tambahan $-4,70$ dan ratio proporsi 0,01 maka pajak hiburan juga termasuk pajak terbelakang dengan kontribusi $0,07 \%$ terhadap total pajak daerah dan $0,02 \%$ terhadap PAD, (4) pajak reklame dengan ratio tambahan 7,46 dan ratio proporsi 0,19 maka pajak reklame termasuk pajak berkembang dengan kontribusi $2,07 \%$ terhadap total pajak daerah dan $0,77 \%$ terhadap PAD, (5) Untuk pajak penerangan jalan dengan ratio tambahan 2,55 dan proporsi 3,05 maka pajak penerangan jalan termasuk pajak prima dengan kontribusi 33,94\% terhadap total pajak daerah dan $12,64 \%$ terhadap PAD, (6) pajak MBLB (galian c) dengan ratio tambahan 0,00 serta proporsinya hanya 1,55 maka pajak MBLB termasuk pajak potensial dengan kontribusi $17,18 \%$ terhadap total pajak daerah dan $6,40 \%$ terhadap PAD, (7) pajak air tanah dengan ratio tambahan 10,44 dan ratio proporsi 0,04 maka pajak air tanah termasuk pajak berkembang dengan kontribusi $0,43 \%$ terhadap total pajak daerah dan $0,16 \%$ terhadap PAD, (8) pajak sarang burung walet dengan ratio tambahan 10,44 dan ratio proporsi 0,04 maka pajak sarang burung walet termasuk pajak berkembang dengan kontribusi $0,43 \%$ terhadap total pajak daerah dan $0,16 \%$ terhadap PAD, dan (9) pajak BPHTB dengan ratio tambahan 5,69 dan ratio proporsinya 1,08 maka pajak BPHTB termasuk pajak potensial dengan kontribusi $12,03 \%$ terhadap total pajak daerah dan $4,48 \%$ terhadap PAD Pertumbuhan atas penerimaan pajak yang dicapai dari tahun 2012 ke 2013 mencapai $-4,79 \%$ dengan rata-rata pendapatan tahun 2013 dari masing-masing ayat pajak sebesar Rp1.293.135.333,00. Dari ke-9 jenis pajak yang termasuk klasifikasi pajak potensial yaitu pajak hotel, MBLB dan BPHTB dan yang masuk dalam katagori klasifikasi Prima yaitu Pajak Restoran dan pajak penerangan jalan. Tiga jenis pajak masuk dalam katagori berkembang yaitu pajak reklame, air tanah dan sarang burung walet serta satu masuk dalam klasifikasi terbelakang yaitu pajak hiburan. Meskipun pajak PPJ (33,94\% dan 12,64\%) dan hotel termasuk pajak prima tapi belum mampu memberikan kontribusi yang signifikan terhadap pajak daerah dan PAD dan diikuti oleh pajak hiburan sebagai penyumbang terendah $0,07 \%$ dan $0,02 \%$. Berdasarkan Tabel 9 maka, khususnya menghubungkan antara ratio tambahan dengan ratio proporsi pajak daerah, maka dapat ditentukan klasifikasi potensi pajak daerah pada tahun 2013 sampai tahun 2014 dapat disimpulkan sebagai berikut: (1) pajak hotel dengan ratio tambahan 0,01 dan ratio Proporsi 1,40 maka pajak hotel termasuk pajak potensial dengan kontribusi $14,01 \%$ terhadap total pajak daerah dan $4,27 \%$ terhadap PAD, (2) pajak restoran dengan ratio tambahan 0,21 dan ratio proporsi 0,97 maka pajak restoran termasuk pajak terbelakang dengan kontribusi $9,70 \%$ terhadap total pajak daerah dan 2,96\% terhadap PAD, (3) pajak hiburan dengan ratio tambahan 0,00 dan ratio proporsi 0,00 maka pajak hiburan juga termasuk pajak terbelakang dengan kontribusi $0,04 \%$ terhadap total pajak daerah dan $0,01 \%$ terhadap PAD, (4) pajak reklame dengan ratio tambahan 0,17 dan ratio proporsi 0,17 maka pajak reklame termasuk pajak terbelakang dengan kontribusi $1,68 \%$ terhadap total pajak daerah dan $0,51 \%$ terhadap PAD, (5) pajak penerangan jalan dengan ratio tambahan 0,12 dan proporsi 2,55 maka pajak penerangan jalan termasuk pajak potensial dengan kontribusi $25,53 \%$ terhadap total pajak daerah dan $7,78 \%$ terhadap PAD, (6) pajak galian $\mathrm{C}$ dengan ratio tambahan 0,08 serta proporsinya hanya 1,22 maka pajak galian $\mathrm{C}$ termasuk pajak potensial dengan kontribusi $12,19 \%$ terhadap total pajak daerah dan $3,71 \%$ terhadap $\mathrm{PAD}$, (7) pajak air tanah dengan ratio tambahan 
0,00 dan ratio proporsi 0,03 termasuk pajak terbelakang dengan kontribusi $0,26 \%$ terhadap total pajak daerah dan $0,08 \%$ terhadap $\mathrm{PAD},(8)$ pajak sarang burung walet dengan ratio tambahan $-0,28$ dan ratio proporsi 0,01 termasuk pajak terbelakang dengan kontribusi $0,13 \%$ terhadap total pajak daerah dan 0,04\% terhadap PAD, (9) pajak BPHTB dengan ratio tambahan 0,12 dan ratio proporsinya 0,90 termasuk pajak terbelakang dengan kontribusi $9,01 \%$ terhadap total pajak daerah dan 2,75\% terhadap PAD, dan (10) Pajak pajak bumi dan bangunan pedesaaan dan perkotaan (PBB P2) dengan ratio tambahan 0,56 dan ratio proporsi 2,75 maka pajak BPHTB termasuk pajak potensial dengan kontribusi $27,45 \%$ terhadap total pajak daerah dan $8,37 \%$ terhadap PAD.

Untuk penerimaan pajak, pertumbuhan yang dicapai dari tahun 2013 ke 2014 mencapai $78,85 \%$ dengan rata-rata pendapatan tahun 2013 dari masing-masing ayat pajak sebesar Rp1.887.259.687,00. Dari ke-9 jenis pajak yang termasuk klasifikasi pajak potensial yaitu pajak hotel, PPJ, MBLB dan PBB P2. Lima jenis pajak masuk dalam katagori terbelakang yaitu pajak restoran, hiburan, reklame, air tanah, sarang burung walet dan BPHTB. Pajak PPJ dan PBB P2 menjadi kontributor terbesar meskipun hanya dibawah $30 \%$ terhadap total pajak daerah dan dibawah $10 \%$ terhadap PAD dan pajak hiburan menjadi penyumbang terendah $0,04 \%$ dan $0,01 \%$. Berdasarkan Tabel 10 maka, khususnya menghubungkan antara ratio tambahan dengan ratio proporsi pajak daerah, maka dapat ditentukan klasifikasi potensi pajak daerah pada tahun 2014 sampai tahun 2015 dapat disimpulkan sebagai berikut: (1) pajak hotel dengan ratio tambahan 0,34 dan ratio Proporsi 1,13 maka pajak hotel termasuk pajak potensial dengan kontribusi
$11,31 \%$ terhadap total pajak daerah dan 3,73\% terhadap PAD, (2) pajak restoran dengan ratio tambahan $-0,60$ dan ratio proporsi 0,65 maka pajak restoran termasuk pajak terbelakang dengan kontribusi $6,50 \%$ terhadap total pajak daerah dan 2,14\% terhadap PAD, (3) pajak hiburan dengan ratio tambahan 1,50 dan ratio proporsi 0,00 maka pajak hiburan juga termasuk pajak berkembang dengan kontribusi $0,03 \%$ terhadap total pajak daerah dan $0,01 \%$ terhadap PAD, (4) pajak reklame dengan ratio tambahan 1,53 dan ratio proporsi 0,27 maka pajak reklame termasuk pajak berkembang dengan kontribusi 2,73\% terhadap total pajak daerah dan $0,90 \%$ terhadap PAD, (5) pajak penerangan jalan dengan ratio tambahan 1,73 dan proporsi 2,82 maka pajak penerangan jalan termasuk pajak prima dengan kontribusi $28,18 \%$ terhadap total pajak daerah dan 9,30\% terhadap PAD, (6) pajak galian $\mathrm{C}$ dengan ratio tambahan 0,76 serta proporsinya hanya 1,78 maka pajak galian $\mathrm{C}$ termasuk pajak potensial dengan kontribusi $17,75 \%$ terhadap total pajak daerah dan $5,86 \%$ terhadap PAD, (7) pajak air tanah dengan ratio tambahan 5,07 dan ratio proporsi 0,02 termasuk pajak berkembang dengan kontribusi $0,21 \%$ terhadap total pajak daerah dan 0,07\% terhadap PAD, (8) pajak sarang burung walet dengan ratio tambahan 25,03 dan ratio proporsi 0,01 termasuk pajak berkembang dengan kontribusi $0,10 \%$ terhadap total pajak daerah dan 0,03\% terhadap PAD, (9) pajak BPHTB dengan ratio tambahan 2,45 dan ratio proporsinya 1,57 termasuk pajak prima dengan kontribusi 15,69\% terhadap total pajak daerah dan 5,18\% terhadap PAD, dan (10) Pajak PBB P2 dengan ratio tambahan 0,56 dan ratio proporsi 1,75 maka pajak BPHTB termasuk pajak potensial dengan kontribusi $17,49 \%$ terhadap total pajak daerah dan $5,78 \%$ terhadap PAD.

Tabel 6. Kontribusi Ayat Pajak Terhadap Pajak Daerah dan PAD

\begin{tabular}{|c|l|c|c|c|c|c|c|}
\hline No & Jenis Pajak & Tahun 2011 & $\begin{array}{c}\text { Kontribusi } \\
\text { terhadap Pajak }\end{array}$ & $\begin{array}{c}\text { Kontribusi } \\
\text { terhadap PAD }\end{array}$ & Tahun 2012 & $\begin{array}{c}\text { Kontribusi } \\
\text { terhadap Pajak }\end{array}$ & $\begin{array}{c}\text { Kontribusi } \\
\text { terhadap PAD }\end{array}$ \\
\hline 1 & Pajak Hotel & 2.525 .000 .000 & 23,47 & 10,29 & 2.570 .000 .0000 & 21,02 & 9,52 \\
\hline 2 & P. Restoran & 1.652 .500 .000 & 15,36 & 6,73 & 1.472 .500 .000 & 12,05 & 5,45 \\
\hline 3 & P. Hiburan & 6.300 .000 & 0,06 & 0,03 & 6.300 .000 & 0,05 & 0,02 \\
\hline 4 & P. Reklame & 245.000 .000 & 2,28 & 1,00 & 375.000 .000 & 3,07 & 2,39 \\
\hline 5 & PPJ & 3.881 .375 .000 & 36,07 & 15,81 & 4.500 .000 .000 & 36,81 & 16,66 \\
\hline 6 & Pajak MBLB & 1.750 .000 .000 & 16,26 & 7,13 & 2.000 .000 .000 & 16,36 & 7,41 \\
\hline 7 & P. Air Tanah & 100.000 .000 & 0,93 & 0,41 & 100.000 .000 & 0,82 & 0,37 \\
\hline 8 & P. Sarang B. Walet & 100.000 .000 & 0,93 & 0,41 & 100.000 .000 & 0,82 & 0,37 \\
\hline 9 & BPHTB & 500.000 .000 & 4,65 & 2,04 & 1.100 .000 .000 & 9,00 & \\
\hline 10 & PBBP2 & & & & & & \\
\hline & Jumlah & 10.760 .175 .000 & 100,00 & 43,84 & 12.223 .800 .000 & 100,00 & \\
\hline & Rata-rata & 1.195 .575 .000 & & & 1.358 .200 .000 & & 45,26 \\
\hline 11 & PAD & 24.544 .538 .719 & 43,84 & & 27.007 .276 .500 & \\
\hline
\end{tabular}




\begin{tabular}{|c|c|c|c|c|c|c|c|c|c|c|}
\hline No & Jenis Pajak & Tahun 2013 & $\begin{array}{c}\text { Kon } \\
\text { terhadap } \\
\text { Pajak }\end{array}$ & $\begin{array}{c}\text { Kon } \\
\text { terhadap } \\
\text { PAD }\end{array}$ & Tahun 2014 & $\begin{array}{c}\text { Kon } \\
\text { terhadap } \\
\text { Pajak }\end{array}$ & $\begin{array}{c}\text { Kon } \\
\text { terhadap } \\
\text { PAD }\end{array}$ & Tahun 2015 & $\begin{array}{c}\text { Kon } \\
\text { terhadap } \\
\text { Pajak }\end{array}$ & $\begin{array}{c}\text { Kon } \\
\text { terhadap } \\
\text { PAD }\end{array}$ \\
\hline 1 & Pajak Hotel & 2.613 .800 .000 & 22,46 & 8,36 & 2.643 .800 .000 & 14,01 & 4,27 & 2.803 .526 .659 & 11,31 & 3,73 \\
\hline 2 & P. Restoran & 1.325 .700 .000 & 11,39 & 4,24 & 1.830 .700 .000 & 9,70 & 2,96 & 1.610 .423 .631 & 6,50 & 2,14 \\
\hline 3 & P. Hiburan & 7.718 .000 & 0,07 & 0,02 & 7.718 .000 & 0,04 & 0,01 & 8.600 .000 & 0,03 & 0,01 \\
\hline 4 & P. Reklame & 241.000 .000 & 2,07 & 0,77 & 316.200 .000 & 1,68 & 0,51 & 676.249 .144 & 2,73 & 0,90 \\
\hline 5 & PPJ & 3.950 .000 .000 & 33,94 & 12,64 & 4.818 .000 .000 & 25,53 & 7,78 & 6.986 .010 .516 & 28,18 & 9,30 \\
\hline 6 & Pajak MBLB & 2.000 .000 .000 & 17,18 & 6,40 & 2.300 .000 .000 & 12,19 & 3,71 & 4.401 .762 .300 & 17,75 & 5,86 \\
\hline 7 & P. Air Tanah & 50.000 .000 & 0,43 & 0,16 & 50.000 .000 & 0,26 & 0,08 & 52.698 .000 & 0,21 & 0,07 \\
\hline 8 & $\begin{array}{l}\text { P. Sarang } \\
\text { B. Walet }\end{array}$ & 50.000 .000 & 0,43 & 0,16 & 25.000 .000 & 0,13 & 0,04 & 25.500 .000 & 0,10 & 0,03 \\
\hline 9 & BPHTB & 1.400 .000 .000 & 12,03 & 4,48 & 1.700 .000 .000 & 9,01 & 2,75 & 3.890 .855 .376 & 15,69 & 5,18 \\
\hline \multirow[t]{3}{*}{10} & PBBP2 & & & & $\begin{array}{l}5.181 .178 .871 \\
\end{array}$ & 27,45 & 8,37 & 4.336 .568 .271 & 17,49 & 5,78 \\
\hline & Jumlah & 11.638 .218 .000 & 100,00 & 37,23 & 18.872 .596 .871 & 100,00 & 30,48 & 24.792 .193 .897 & 100,00 & 33,02 \\
\hline & Rata-rata & 1.293 .135 .333 & & & 1.887 .259 .687 & & & 2.754 .688 .211 & & \\
\hline 11 & PAD & 31.256 .367 .000 & 37,23 & & 61.922 .781 .924 & 30,48 & & 75.084 .091 .894 & 33,02 & \\
\hline
\end{tabular}

\begin{tabular}{|c|c|c|c|c|c|c|c|}
\hline No & Jenis Pajak & Tahun 2011 & Tahun 2012 & Pertum & Ratio Pertum b & Elastisitas & Ratio Prop \\
\hline 1 & Pajak Hotel & 2.525 .000 .000 & 2.570 .000 .0000 & 1,78 & 0,13 & 0,13 & 1,89 \\
\hline 2 & P. Restoran & 1.652 .500 .000 & 1.472 .500 .000 & $-10,89$ & $-0,80$ & $-0,80$ & 1,08 \\
\hline 3 & P. Hiburan & 6.300 .000 & 6.300 .000 & 0,00 & 0,00 & 0,00 & 0,00 \\
\hline 4 & P. Reklame & 245.000 .000 & 375.000 .000 & 53,06 & 3,90 & 3,90 & 0,28 \\
\hline 5 & PPJ & 3.881 .375 .000 & 4.500 .000 .000 & 15,94 & 1,17 & 1,17 & 3,31 \\
\hline 6 & Pajak MBLB & 1.750 .000 .000 & 2.000 .000 .000 & 14,29 & 1,05 & 1,05 & 1,47 \\
\hline 7 & P. Air Tanah & 100.000 .000 & 100.000 .000 & 0,00 & 0,00 & 0,00 & 0,07 \\
\hline 8 & P. Sarang B. Walet & 100.000 .000 & 100.000 .000 & 0,00 & 0,00 & 0,00 & 0,07 \\
\hline 9 & BPHTB & 500.000 .000 & 1.100 .000 .000 & 120,00 & 8,82 & 8,82 & 0,81 \\
\hline \multirow[t]{3}{*}{10} & PBBP2 & & & & & & \\
\hline & Jumlah & 10.760 .175 .000 & 12.223 .800 .000 & 13,60 & 14,28 & 14,3 & 9,00 \\
\hline & Rata-rata & 1.195 .575 .000 & 1.358 .200 .000 & 1,51 & 1,59 & 1,59 & 1,00 \\
\hline
\end{tabular}

Tabel 8. Ratio Pertumbuhan, Pertambahan dan Ratio Proporsi Pajak Daerah Kabupaten Minahasa Tahun 2012-2013

\begin{tabular}{|c|c|c|c|c|c|c|c|}
\hline No & Jenis Pajak & Tahun 2012 & Tahun 2013 & Pertum & Ratio Pertum b & Elastisitas & Ratio Prop \\
\hline 1 & P. Hotel & 2.570 .000 .0000 & 2.613 .800 .000 & 1,70 & $(0,36)$ & $-0,36$ & 2,02 \\
\hline 2 & P. Restoran & 1.472 .500 .000 & 1.325 .700 .000 & $-9,97$ & 2,08 & 2,08 & 1,03 \\
\hline 3 & P. Hiburan & 6.300 .000 & 7.718 .000 & 22,51 & $(4,70)$ & $-4,70$ & 0,01 \\
\hline 4 & P. Reklame & 375.000 .000 & 241.000 .000 & $-35,73$ & 7,46 & 7,46 & 0,19 \\
\hline 5 & PPJ & 4.500 .000 .000 & 3.950 .000 .000 & $-12,22$ & 2,55 & 2,55 & 3,05 \\
\hline 6 & Pajak MBLB & 2.000 .000 .000 & 2.000 .000 .000 & 0,00 & - & 0,00 & 1,55 \\
\hline 7 & P. Air Tanah & 100.000 .000 & 50.000 .000 & $-50,00$ & 10,44 & 10,44 & 0,04 \\
\hline 8 & P. Sarang B. Walet & 100.000 .000 & 50.000 .000 & $-50,00$ & 10,44 & 10,44 & 0,04 \\
\hline 9 & ВPHTB & 1.100 .000 .000 & 1.400 .000 .000 & 27,27 & $(5,69)$ & $\begin{array}{l}-5,69 \\
\end{array}$ & 1,08 \\
\hline \multirow[t]{3}{*}{10} & PBBP2 & & - & & & & \\
\hline & Jumlah & 12.223 .800 .000 & 11.638 .218 .000 & $-4,79$ & 22,2 & 22,2 & 9,0 \\
\hline & Rata-rata & 1.358 .200 .000 & 1.293 .135 .333 & $(0,53)$ & 2,47 & 2,47 & 1,00 \\
\hline
\end{tabular}

Tabel 9. Ratio Pertumbuhan, Pertambahan dan Ratio Proporsi Pajak Daerah Kabupaten Minahasa Tahun 2013-2014

\begin{tabular}{|c|c|c|c|c|c|c|c|}
\hline No & Jenis Pajak & Tahun 2013 & Tahun 2014 & Pertum & Ratio Pertum b & Elastisitas & Ratio Prop \\
\hline 1 & P. Hotel & 2.613 .800 .000 & 2.643 .800 .000 & 1,15 & 0,01 & 0,02 & 1,40 \\
\hline 2 & P. Restoran & 1.325 .700 .000 & 1.830 .700 .000 & 38,09 & 0,48 & 0,61 & 0,79 \\
\hline 3 & P. Hiburan & 7.718 .000 & 7.718 .000 & 0,00 & 0,00 & - & 0,00 \\
\hline 4 & P. Reklame & 241.000 .000 & 316.200 .000 & 31,20 & 0,40 & 0,50 & 0,17 \\
\hline 5 & PPJ & 3.950 .000 .000 & 4.818 .000 .000 & 21,97 & 0,28 & 0,35 & 2,55 \\
\hline 6 & Pajak MBLB & 2.000 .000 .000 & 2.300 .000 .000 & 15,00 & 0,19 & 0,24 & 1,22 \\
\hline 7 & P. Air Tanah & 50.000 .000 & 50.000 .000 & 0,00 & 0,00 & - & 0,03 \\
\hline 8 & P. Sarang B. Walet & 50.000 .000 & 25.000 .000 & $-50,00$ & $-0,63$ & $(0,80)$ & 0,01 \\
\hline 9 & BPHTB & 1.400 .000 .000 & 1.700 .000 .000 & 21,43 & 0,27 & 0,34 & 0,90 \\
\hline \multirow[t]{3}{*}{10} & PBBP2 & 0 & 5.181 .178 .871 & 0 & 0,00 & - & 2,75 \\
\hline & Jumlah & 11.638 .218 .000 & 18.872 .596 .871 & 78,85 & 1,00 & 1,27 & 10 \\
\hline & Rata-rata & 1.293 .135 .333 & 1.887 .259 .687 & 7,88 & 0,10 & 0,13 & 1 \\
\hline
\end{tabular}

Tabel 10. Ratio Pertumbuhan, Pertambahan dan Ratio Proporsi Pajak Daerah Kabupaten Minahasa Tahun 2014-2015

\begin{tabular}{|c|c|c|c|c|c|c|c|}
\hline No & Jenis Pajak & Tahun 2014 & Tahun 2015 & Pertum & Ratio Pertum b & Elastisitas & Ratio Prop \\
\hline 1 & P. Hotel & 2.562 .338 .293 & 2.803 .526 .659 & 9,41 & 0,34 & 1,34 & 1,13 \\
\hline 2 & P. Restoran & 1.925 .240 .171 & 1.610 .423 .631 & $-16,35$ & $-0,60$ & $-0,60$ & 0,65 \\
\hline 3 & P. Hiburan & 6.100 .000 & 8.600 .000 & 40,98 & 1,50 & 1,50 & 0,00 \\
\hline 4 & P. Reklame & 476.307 .859 & 676.249 .144 & 41,98 & 1,53 & 1,53 & 0,27 \\
\hline 5 & PPJ & 4.739 .516 .629 & 6.986 .010 .516 & 47,40 & 1,73 & 1,73 & 2,82 \\
\hline 6 & Pajak MBLB & 3.644 .246 .400 & 4.401 .762 .300 & 20,79 & 0,76 & 0,76 & 1,78 \\
\hline 7 & P. Air Tanah & 22.089 .250 & 52.698 .000 & 138,57 & 5,07 & 5,07 & 0,02 \\
\hline 8 & P. Sarang B. Walet & 3.250 .000 & 25.500 .000 & 684,62 & 25,03 & 25,03 & 0,01 \\
\hline 9 & BPHTB & 2.328 .199 .604 & 3.890 .855 .376 & 67,12 & 2,45 & 2,45 & 1,57 \\
\hline 10 & PBBP2 & 3.760 .771 .464 & 4.336 .568 .271 & 15,31 & 0,56 & 0,56 & 1,75 \\
\hline & Jumlah & 19.468 .059 .670 & 24.792 .193 .897 & 27,35 & 38,39 & 38 & 10 \\
\hline & Rata-rata & 1.946 .805 .967 & 2.479 .219 .390 & 2,73 & 3,84 & 4 & 1 \\
\hline
\end{tabular}


Untuk penerimaan pajak, pertumbuhan yang dicapai dari tahun 2014 ke 2015 mencapai $27,35 \%$ dengan rata-rata pendapatan tahun 2013 dari masing-masing ayat pajak sebesar Rp532.413.423,00. Dari ke-9 jenis pajak yang termasuk klasifikasi pajak potensial yaitu pajak hotel, MBLB dan PBB P2. Pajak PPJ dan pajak BPHTB termasuk pajak prima. Pajak hiburan, reklame, air tanah, sarang burung walet termasuk pajak berkembang dan pajak restoran termasuk dalam kategori pajak terbelakang. Meskipun pajak PPJ termasuk pajak prima tapi belum memberikan kontribusi yang besar terhadap pajak daerah dan PAD. Jika termasuk dalam kategori Prima maka harus dipertahankan. Jika termasuk dalam kategori potensial maka yang dilakukan adalah mengintensifkan yang sudah ada biar tercapai pertumbuhan. Berdasarkan uraian diatas, klasifikasi jenis pajak atas ratio pertumbuhan dan ratio proporsi tahun 2012-2015. Tabel 11 menunjukan bahwa secara umum pajak hotel dan pajak MBLB merupakan pajak pajak potensial serta pajak penerangan jalan (PPJ) merupakan pajak dengan kategori pajak prima. Sedangkan pajak BPHTB dinamis dan pajak hiburan merupakan pajak terbelakang. Diketahui juga bahwa kontribusi masing-masing pajak tidak merata dan prosentase pajak darah terhadap PAD hanya berada pada range $30 \%$ dan tidak melebihi $50 \%$. Sesuai dengan prosentase tingkat kemandirian daerah maka suatu daerah dikatakan menjadi daerah yang mandiri yang mampu membiayai kebutuhan/pengeluaran harus mempunyai pendapatan asli daerah mencapai $60 \%$ lebih. Hal ini kemudian dapat diambil kesimpulan bahwa dalam kurun waktu 5 (lima) tahun dari tahun 2011-2015, Pemerintah Kabupaten Minahasa belum bisa menjadi daerah yang mandiri sehingga masih membutuhkan bantuan baik dari pemerintah pusat, daerah lain maupun para investor.

\section{Analisis Elastisitas Pajak Daerah terhadap PDRB Tahun 2011-2015}

Pengukuran elastisitas ini untuk menunjukkan kemampuan untuk menghasilkan tambahan pendapatan agar dapat mengimbangi kenaikan dalam pengeluaran pemerintah dengan dasar pengenaan pajak selalu berkembang secara otomatis (Davey, 1988). Elastisitas ini mampu untuk melihat derajat kepekaan terhadap jumlah PDRB di Kabupaten Minahasa Tahun 2011 sampai dengan 2015. Untuk menghitung elastisitas penerimaan (EP) dapat dilakukan dengan membandingkan persentase perubahan penerimaan pajak daerah di Kabupaten Minahasa dengan persentase perubahan jumlah produk domestic regional bruto (PDRB) Kabupaten Minahasa dalam kurun waktu Tahunn 20011 sampai dengan 2015 dapat dilihat pada Tabel 12. Tabel 12 menunjukan bahwa hasil perhitungan elastisitas pajak daerah Kabupaten Minahasa pada periode 2011 - 2015 terhadap PDRB atas dasar jumlah nilai produksi pendapatan maupun pengeluaran yang dinilai atas dasar harga tetap (harga pada tahun dasar) yang digunakan selama satu tahun. Dari hasil perhitungan tersebut pada tabel memiliki hasil positif maka dapat disimpulkan bahwa sangat berpotensi.

Tabel 11. Klasifikasi Pajak atas Ratio Pertumbuhan dan Ratio Proporsi

\begin{tabular}{|c|c|c|c|c|c|}
\hline No & Jenis Pajak & Tahun 2012 & Tahun 2013 & Tahun 2014 & Tahun 2015 \\
\hline 1 & P. Hotel & Potensial & Potensial & Potensial & Potensial \\
\hline 2 & P. Restoran & Potensial & Prima & Terbelakang & Terbelakang \\
\hline 3 & P. Hiburan & Terbelakang & Terbelakang & Terbelakang & Berkembang \\
\hline 4 & P. Reklame & Berkembang & Berkembang & Terbelakang & Berkembang \\
\hline 5 & PPJ & Prima & Prima & Potensial & Prima \\
\hline 6 & Pajak MBLB & Prima & Potensial & Potensial & Potensial \\
\hline 7 & P. Air Tanah & Terbelakang & Berkembang & Terbelakang & Berkembang \\
\hline 8 & P. Sarang B. Walet & Terbelakang & Berkembang & Terbelakang & Berkembang \\
\hline 9 & BPHTB & Berkembang & Potensial & Terbelakang & Prima \\
\hline 10 & PBBP2 & & & Potensial & Potensial \\
\hline
\end{tabular}

Tabel 12. Elastisitas Pajak Daerah terhadapn PDRB Kabupaten Minahasa Tahun 2011-2015

\begin{tabular}{|l|c|c|c|c|c|}
\hline Tahun & Pajak Daerah & Pertum b & PDRB (juta) & Pertum b & Elastisitas \\
\hline 2011 & P. Hotel & 0,00 & 24.340 .000 & 0,00 \\
\hline 2012 & P. Restoran & 13,60 & 27.000 .000 & 0,00 \\
\hline 2013 & P. Hiburan & $(4,79)$ & 29.900 .000 & 0,11 \\
\hline 2014 & P. Reklame & 62,16 & 30.570 .000 & 0,11 \\
\hline 2015 & PPJ & 27,80 & $36,570.000$ & 0,02 & 0,215362 \\
\hline Rata-rata & & & 24,26141 \\
\hline
\end{tabular}




\section{Analisis deret berkala (time series trend)}

Kecenderungan/perkiraan penerimaan pajak daerah untuk tahun tahun berikut dapat dilihat pada Tabel 13.

$$
\begin{array}{ll}
\multicolumn{2}{c}{\text { Rumus }: \mathrm{Y}=\mathrm{a}+\mathrm{bT}} \\
\mathrm{a}=77.415 .338 .638 / 5 & \mathrm{a}=15.483 .067 .728 \\
\mathrm{~b}=38.481 .441 .154 / 10 & \mathrm{~b}=3.848 .144 .115,4 \\
\mathrm{Y}=15.483 .067 .728+3.848 .144 .115,4 * \mathrm{~T}
\end{array}
$$

Berdasarkan rumus tersebut maka prediksi pajak daerah 5 tahun mendatang (2016-2020) dapat dilhat pada Tabel 14.

\section{Variabel Keadilan (Equity), efisiensi} (economic efficiency), kemampuan melaksanakan (Ability to implement) dan variabel kesesuaian sebagai penerimaan daerah (Suitability as a Local Source).

Dari hasil perhitungan secara rata-rata selama tahun penelitian tahun 2011-2015 dapat dijelaskan bahwa pajak daerah yang mempunyai pertumbuhan terkecil adalah pajak restoran yaitu sebesar 8,22. Hal ini disebabkan karena adanya iklim usaha restoran yang bekembang tapi belum didukung dengan arus lalu lintas, objek-objek pariwisata yang belum tereksplorasi dan terekspose ke luar daerah. Hal ini menunjukkan bahwa sumber pendapatan selain pajak sangat potensial untuk dilakukan dan ditingkatkan sebagai sumber pendapatan pajak daerah di Kabupaten Minahasa seperti dalam Tabel 15. Dari olahan data rata-rata tahun 2011-2015 dapat dijelaskan bahwa : sumber pendapatan pajak daerah mempunyai nilai tertinggi yaitu pajak BPHTB sebesar 1,53 disusul dengan pajak MBLB dengan nilai sebesar 1,15 persen. Hal ini sebenarnya masih banyak sumber-sumber potensial dari pajak daerah, khususnya pendapatan asli daerah yang bisa dikelola dan dikembangkan. Khususnya pajak hotel, pajak restoran dan pajak daerah lainnya yang persentasenya tidak terlalu jauh sehingga perlu dioptimalkan. Tabel 15 menunjukan bahwa pada tahun 2011-2014 rata-rata peningkatan dibawah $1 \%$. Hal ini menggambarkan bahwa tingkat efektifitas pajak daerah masih kurang. Pada tahun 2015 tingkat efektifitas diatas $1 \%$. Hal ini menandakan telah terdapat perhitungan yang akurat atas potensi pajak yang ada.

Tabel 13. Analisis Trend dengan metode kuadrat terkecil

\begin{tabular}{|c|c|c|c|c|c|c|c|}
\hline \multirow{2}{*}{ No } & \multirow[b]{2}{*}{ Jenis Pajak } & \multicolumn{2}{|c|}{ Tahun 2011} & \multirow{2}{*}{$\mathrm{R} / \mathrm{T} \%$} & \multicolumn{2}{|c|}{ Tahun 2012} & \multirow{2}{*}{$\mathrm{R} / \mathrm{T} \%$} \\
\hline & & Target & Realisasi & & Target & Realisasi & \\
\hline 1 & Pajak Hotel & 2.525 .000 .000 & 2.538 .442 .404 & 1,01 & 2.570 .000 .000 & 1.664 .617 .115 & 0,65 \\
\hline 2 & Pajak Restoran & 1.652 .500 .000 & 1.075 .395 .479 & 0,65 & 1.472 .500 .000 & 1.087 .251 .480 & 0,74 \\
\hline 3 & Pajak Hiburan & $6,300,000$ & 7.718 .000 & 1,23 & 6.300 .000 & 4.208 .000 & 0,67 \\
\hline 4 & Pajak Reklame & 245.000 .000 & 227.787 .433 & 0,93 & 375.000 .000 & 217.404 .667 & 0,58 \\
\hline 5 & PPJ & $3,881.375 .000$ & 3.974 .462 .836 & 1,02 & 4.500 .000 .000 & 3.519 .610 .15 & 0,78 \\
\hline 6 & Pajak MBLB & 1.750 .000 .000 & 1.140 .562 .000 & 0,65 & 2.000 .000 .000 & 2.192 .631 .800 & 1,10 \\
\hline 7 & Pajak Air Tanah & 100.000 .000 & 21.727 .343 & 0,22 & 100.000 .000 & 42.982 .850 & 0,43 \\
\hline 8 & P. Sarang B. Walet & 100.000 .000 & 22.277 .800 & 0,22 & 100.000 .000 & 18.000 .000 & 0,18 \\
\hline 9 & BPHTB & 500.000 .000 & 1.067 .620 .968 & 2,14 & 1.100 .000 .000 & 1.672 .310 .957 & 1,52 \\
\hline \multirow[t]{2}{*}{10} & PBBP2 & 0 & 0 & 0 & 0 & 0 & 0 \\
\hline & Rata-rata & & & 0,90 & & & 0,74 \\
\hline
\end{tabular}

\begin{tabular}{|l|l|c|c|c|c|}
\hline No & Jenis Pajak & Y & T & Y*T & T2 \\
\hline 1 & Tahun 2011 & 10.075 .994 .263 & -2 & $(20.151 .988 .526)$ \\
\hline 2 & Tahun 2012 & 10.419 .017 .784 & -1 & $(10.419 .017 .784)$ \\
\hline 3 & Tahun 2013 & 12.660 .073 .024 & 0 & - & 1 \\
\hline 4 & Tahun 2014 & 19.468 .059 .670 & 1 & - & 19.468 .059 .670 \\
\hline 5 & Tahun 2015 & 24.790 .193 .897 & 2 & 49.584 .387 .794 & 1 \\
\hline & & 77.415 .338 .638 & & 38.481 .441 .154 & 4 \\
\hline
\end{tabular}

\begin{tabular}{|c|c|c|c|c|c|c|c|c|}
\hline \multicolumn{2}{|l|}{ Tahun 2013} & \multirow{2}{*}{$\mathrm{R} / \mathrm{T} \%$} & \multicolumn{2}{|l|}{ Tahun 2014} & \multirow[b]{2}{*}{$\mathbf{R} / \mathbf{T} \%$} & \multicolumn{2}{|l|}{ Tahun 2015} & \multirow{2}{*}{$\mathbf{R} / \mathbf{T} \%$} \\
\hline Target & Realisasi & & Target & Realisasi & & Target & Realisasi & \\
\hline 2.613 .800 .000 & 2.730 .462 .904 & 1,04 & 2.643 .800 .000 & 2.562 .338 .293 & 0,97 & 3.053 .100 .000 & 2.803 .526 .659 & 0,92 \\
\hline 1.325 .700 .000 & 1.197 .773 .06 & 0,90 & 1.830 .700 .000 & 1.925 .240 .171 & 1,05 & 1.682 .750 .000 & 1.610 .423 .631 & 0,96 \\
\hline 7.718 .000 & 3.225 .000 & 0,42 & 7.718 .000 & 6.100 .000 & 0,79 & 8.000 .000 & 8.600 .000 & 1,08 \\
\hline 241.000 .000 & 285.909 .823 & 1,19 & 316.200 .000 & 476.307 .859 & 1,51 & 576.000 .000 & 676.249 .144 & 1,17 \\
\hline 3.950 .000 .000 & 3.887 .999 .024 & 0,98 & 4.818 .000 .000 & 4.739 .516 .629 & 0,98 & 6.000 .000 .000 & 6.986 .010 .516 & 1,16 \\
\hline 2.000 .000 .000 & 2.596 .743 .000 & 1,30 & 2.300 .000 .000 & 3.644 .246 .400 & 1,58 & 4.000 .000 .000 & 4.401 .762 .300 & 1,10 \\
\hline 50.000 .000 & 28.867 .500 & 0,58 & 50.000 .000 & 22.089 .250 & 0,44 & 50.000 .000 & 52.698 .000 & 1,05 \\
\hline 50.000 .000 & 21.500 .000 & 0,43 & 25.000 .000 & 3.250 .000 & 0,13 & 25.000 .000 & 25.500 .000 & 1,02 \\
\hline 1.400 .000 .000 & 1.907 .592 .704 & 1,36 & 1.700 .000 .000 & 2.328 .199 .604 & 1,37 & 3.125 .000 .000 & 3.890 .855 .376 & 1,25 \\
\hline \multirow[t]{2}{*}{0} & 0 & 0 & 5.181 .178 .871 & 3.760 .771 .464 & 0,73 & 5.600 .000 .000 & 4.336 .568 .271 & 0,77 \\
\hline & & 0,91 & & & 0,96 & & & 1,05 \\
\hline
\end{tabular}

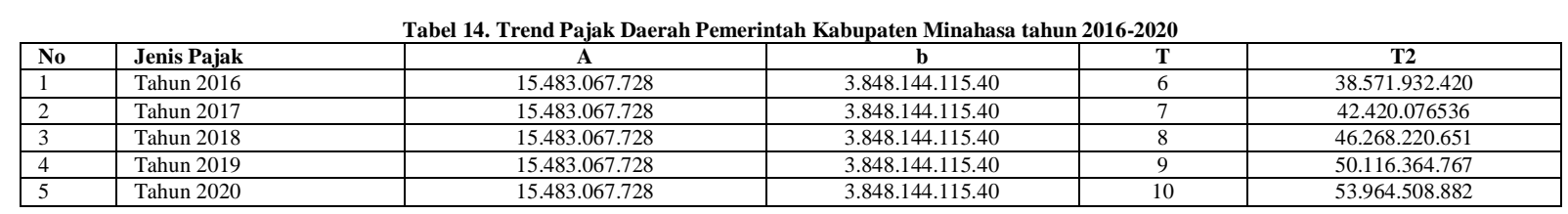

Table 15. Target dan Realisasi Pajak Daerah Tahun 2011-2015 


\section{KESIMPULAN DAN SARAN}

\section{Kesimpulan}

Target penerimaan pajak daerah harus berdasarkan pada potensi penerimaan pajak atas objek pajak yang ada di Kabupaten Minahasa bukan berdasarkan incremental (peningkatan) sebesar sekian persen dibanding realisasi tahuntahun sebelumnya. Kontribusi pajak daerah terhadap pendapatan asli daerah kurun waktu 2011-2015 masih di bawah 50\% dan Pendapatan Asli Daerah berada di level $5 \%$ atas Pendapatan Dana Transfer Pemerintah Pusat ke daerah. Hal ini mengakibatkan tingkat kesejahteraan dan kemakmuran penduduk masih kurang yang digambarkan dengan tingkat pendapatan perkapita masih kurang dan tingkat kemandirian daerah masih jauh dari harapan. Pajak hotel diklasifikasikan pajak potensial, pajak restoran diklasifikasikan potensial, pajak hiburan terbelakang, pajak reklame diklasifikasikan berkembang, pajak penerangan jalan (PPJ) diklasifikasikan prima, pajak mineral bukan logam dan batuan (MBLB) diklasifikasikan potensial, pajak air tanah terbelakang, pajak sarang burung walet diklasifikasikan terbelakang, pajak bea perolehan hak tanah dan bangunan (BPHTB) diklasifikasikan potensial dan pajak bumi bangunan pedesaan dan perkotaan (PBBP2) diklasifikasikan potensial. Analisis tren pajak daerah untuk tahun 2016-2020 mengalami peningkatan dibawah 5 (lima) miliar rupiah setiap tahunnya sehingga perlu ditingkatkan.

\section{Saran}

Berdasarkan kesimpulan di atas sebagai masukan dan penulis mengajukan saran untuk pihak-pihak yang berkepentingan khususnya Dinas Pendapatan Daerah Kabupaten Minahasa yang pada tahun 2017 berubah nama menjadi Badan Pengelola Pajak dan Retribusi Daerah sebagai berikut:

1. Pemerintah Kabupaten Minahasa harus mengetahui potensi dan tingkat pertumbuhan sehingga dapat menetapkan target pendapatan pajak daerah secara rasionalnya sehingga dalam perencanaan dan penganggaran lebih tepat dan terukur berdasarkan data yang akurat yang telah tervalidasi di lapangan., harus kreatif, proaktif dan inovatif dalam melihat peluang-peluang dalam meningkatkan penerimaan pajak daerah serta perlu mencari objek pajak baru/lain tanpa mengabaikan aturan yang berlaku.

2. Pemerintah Kabupaten Minahasa perlu memperhatikan kategori/klasifikasi potensi pajak. Jika termasuk pajak dalam kategori prima, maka harus mempertahankan/ mengoptimalkan, jika kategori potensial maka yang dilakukan adalah mengintensifkan yang sudah ada biar tercapai pertumbuhan, tetapi jika termasuk penerimaan berkembang dan terbelakang, maka perlu adanya evaluasi, apakah sumber penerimaan yang menguntungkan atau jenis akan merugikan. Selain itu pentingnya juga dilakukan pengawasan dan monitoring yang memadai oleh pihak internal (pemerintah) dan eksternal (masyarakat) terhadap sistem penerimaan penerimaan pajak daerah, sejak penetapan objek pajak sampai pada penyetoran ke kas daerah sehingga mengurangi penyimpangan dan penyalagunaan.

3. Pelaksanaan sosialisasi tentang pajak daerah kepada masyarakat terlebih sosialisasi Peraturan tentang Perpajakan kepada masyarakat dan arti pentingnya pajak bagi pembangunan daerah.

\section{DAFTAR PUSTAKA}

Abdul Halim. 2004. Manajemen Keuangan Daerah. UPP AMP YKPN. Yogyakarta.

Bachrul Elmi. 2002. Keuangan Pemerintah Daerah Otonomi di Indonesia. Penerbit Universitas Indonesia. Jakarta.

Brotodihardjo, R. Santoso. 2003. Pengantar Ilmu Hukum Pajak. Bandung: PT Refika Aditama.

Davey, K.J, 1988. Pembiayaan Pemerintah Daerah. Jakarta : PT. Gramedia Pustaka Utama.

Halim (2010). Dasar - Dasar Akuntansi Biaya Jakarta: Salemba Empat.

Kabupaten Minahasa, Peraturan Bupati No. 6 tahun 2011 Tentang Sistem, Prosedur dan Sanksi Pemungutan Pajak Daerah Pemerintah Kabupaten Minahasa.

Kabupaten Minahasa, Peraturan Daerah No. 1 tahun 2011 Tentang Pajak Daerah Pemerintah Kabupaten Minahasa. 
Lalu Karyawan. 2002, Efisiensi, Efektivitas dan Elastisitas Pajak Hotel dan Restoran di Kota Mataram Nusa Tenggara Barat. Tesis S2 Program Pasca Sarjana MEP UGM. Yogyakarta (tidak dipublikasikan).

Mardiasmo dan Akhmad Makhfatih. 2000. Perhitungan Potensi Pajak dan retribusi daerah di Kabupaten Magelang. Laporan Penelitian, PAU Studi Ekonomi UGM ,Yogyakarta.

Mardiasmo, 2001. Perpajakan. Yogyakarta: Penerbit Andi.

Musgrave, Richard A. dan Peggy Musgrave. 1990. Keuangan Negara dalam Teori dan Praktek (edisi Bahasa Indonesia) Jakarta: Penerbit Erlangga.

Masykur Wiratmo, 2001 Manajemen Penggalian Potensi Penerimaan Daerah, makalah.

Mohammad Riduansyah. 2003. Kontribusi Pajak Daerah dan Retribusi Daerah Terhadap Pendapatan Asli Daerah (PAD) dan Anggaran Pendapatan dan Belanja Daerah (APBD) Guna Mendukung Pelaksanaan Otonomi Daerah (Studi Kasus Pemerintah Daerah Kota Bogor) Jurnal Makara, Sosial Humaniora.Vol.7, No.2, Desember. Hal. 49-57

Rachmat Soemitro (2004) 1990. Azas Dan Dasar Perpajakan Jilid 1. Eresco: Bandung.

Rahayu, Ning dan Imam Santoso (2007). Bunga Rampai Perpajakan Indonesia. FISIP UI, Jakarta.

Raksaka Mahi.2005. Peran Pendapatan Asli Daerah di Era Otonomi. Jurnal Ekonomi dan Pembangunan Indonesia. Universitas Indonesia

Republik Indonesia, Peraturan Pemerintah nomor 65 tahun 2001 (pasal 1 ayat 1) Tentang Pajak Daerah.
Republik Indonesia, Undang-Undang No. 18 Tahun 1997 Tentang Pajak Daerah dan Retribusi Daerah.

Republik Indonesia, Undang-Undang No. 34 tahun 2000 Tentang Pajak Daerah Dan Retribusi Daerah.

Republik Indonesia, Undang-Undang No. 17 Tahun 2003 Tentang Keuangan Negara.

Republik Indonesia, Undang-Undang No.1 Tahun 2004 Tentang Perbendaharaan Negara.

Republik Indonesia, Undang-Undang No. 34 Tahun 2004 Tentang Perimbangan Keuangan antara Pemerintah Pusat dan Pemerintah Daerah.

Republik Indonesia, Undang-Undang No.28 Tahun 2009 Tentang Pajak Daerah dan Retribusi Daerah.

Republik Indonesia, Undang-Undang No. 23 Tahun 2014 Tentang Pemerintahan Daerah.

Sunarto (2005:15). Pajak dan Retribusi Daerah, Yogyakarta : AMUS dan Citra Pustaka.

Wahyuni, 2010. Perimbangan Keuangan Pusat dan Daerah, Yogyakarta. 